Title:

Authors:

Mailing address:

Corresponding:

Key words:

Impact statement:
The psychological appeal of owning private land for conservation

Jennifer Gooden, Richard Grenyer

OUCE, South Parks Road, Oxford OX1 3PQ, UK

Jennifer Gooden, Oxford University Centre for the Environment, Oxford

OX13PQ, UK, jennifer.gooden@ouce.ox.ac.uk

autonomy, eudaimonia, extrinsic motivation, grounded theory, intrinsic motivation, personal projects, philanthropy, psychology, well-being

To be effective, private land conservation programs should recognize and foster landowner engagement in conservation projects.

\begin{abstract}
Continued threats to global biodiversity have stimulated interest in the private purchase of land for conservation. Though not a new phenomenon, private land conservation appears to be on the rise, and its ambiguous position between philanthropy and financial investment leads to questions about the nature of landowner motives. Based on grounded theory analysis of interviews with the owners of privately conserved areas (PCAs), we find that individual landowners' involvement in private land conservation is driven, in part, by a desire for meaningful personal engagement in a project. This paper presents a model of PCA engagement in which landowners become personally invested in the management of the PCA and in the nature they protect. By looking at what landowners have in common across a variety of cultural and policy contexts, we show that landowners' engagement in PCAs as a meaningful project contributes to their well-being and, moreover, that PCAs can be conceptualized not merely as philanthropic endeavors, nor merely investments, but as meaningful projects in which their owners engage. Notably, fundamental psychological drives for autonomy, efficacy, and social connection facilitate the engagement process, regardless of whether conservation motivation is intrinsic or extrinsic. Our findings suggest that land conservation programs might consider i) allowing landowner autonomy to the maximum extent possible, ii) developing best practice standards against which landowners can assess their efficacy, and iii) facilitating the development of landowner networks.
\end{abstract}

This article has been accepted for publication and undergone full peer review but has not been through the copyediting, typesetting, pagination and proofreading process, which may lead to differences between this version and the Version of Record. Please cite this article as doi: 10.1111/cobi.13215. 


\section{The psychological appeal of owning private land for conservation}

\section{Introduction}

Continued decline in biodiversity has stimulated interest in private land conservation (PLC) to augment state-owned protected areas (Stolton et al. 2014). Though PLC is not a new phenomenon, it appears to be increasing (Drescher \& Brenner 2018) and is relatively prevalent throughout North America, parts of Latin America, Australia, western and northern Europe, and eastern and southern Africa (Kamal et al. 2015; Stolton et al. 2014).

Interest in PLC occurs against the backdrop of neoliberal rollback of state programs and a decline in public resources for conservation (Castree 2008). PLC's position in the liminal space between philanthropy and financial investment (Fairfax et al. 2005) has prompted interest in landowner motives and questions about its nature: is PLC charitable or self-interested? This question is not merely academic; the way conservation is conceptualized affects public perception of its contribution to the greater good and, consequently, the range of acceptable policy instruments.

In this study, we explore the motives of individuals who own a privately conserved area (PCA), either by purchasing land with an existing PCA or creating a PCA on their own land. We defined a PCA as privately-owned land for which conservation was a main (but not necessarily sole) objective, from the perspective of the landowners. IUCN includes six types of ownership in its definition of private governance: NGOs, corporations, for-profit entities, religious organizations, research institutions, and individuals (Stolton et al. 2014). Here, we focus on individuals who actively initiate private land conservation. Conservation actions varied across properties; examples included reintroduction of fauna, reforestation, wetland restoration, protection from development, education and awareness activities, protection from development and poaching, and making the property available to researchers.

Studies examining the motives behind pro-environmental behavior are common within the conservation literature (Kabii \& Horowitz 2006), where motives are often categorized as either values-driven or incentive-based (van den Born et al. 2017). For example, volunteers in an invasive plant species removal program reported that caring for nature and expressing their values were among their top motives (Pagès et al. 2017). Similarly, landowners report that they conserve land to take action aligned with their values, personal norms, and identity (Farmer et al. 2011, Lokhorst et al. 2011). On the other hand, incentive payments increase participation in conservation programs (e.g., Ciuzio et al. 2013). Financial payments and other direct benefits, such as technical assistance, can also increase environmental conservation on private land (Fairfax et al. 2005; Selinske et al. 2015). Landowners can and do respond to incentives, but many report that financial incentives merely provide a means to implement prior conservation ambitions (Ernst \& Wallace 2008, Farmer et al. 2011). Diverse incentives appeal to participants in different contexts, for different interventions, with different values (Rogers 1995).

In addition to values and incentives, meaningful goal-driven activity is essential to psychological well-being (Ryan \& Deci 2000), a finding that is robust across cultures and geographic regions (Fischer \& Schwartz 2010). Motives that emphasize living a subjectively meaningful and worthwhile life have been identified in conservation; for example, van den Born et al. (2017) found that 
committed conservation actors are driven by their belief that nature contributes to a meaningful life. Similar motives have been demonstrated in participants in an invasive plant species eradication program (Pagès et al. 2017) and rural residents (Drescher 2014). However, we believe this type of motive has not been examined in the context of PCAs owned by individuals. Here we begin to close that gap, finding that PCAs should be conceptualized not merely as philanthropic endeavors, nor merely investments, but also as meaningful projects in which their owners engage.

Landowner motives are typically ascertained using surveys or structured interviews in a specific geographic area. In this study, instead of assessing the motives of spatially-clustered landowners, we used grounded theory and theoretical sampling (see Methods) to identify individuals who appear to be highly motivated and able to conserve land: 27 PCA owners in 13 countries who have themselves purchased PCA or created a PCA on their own land. By looking at what members of this group have in common across a variety of cultural and policy contexts, we have developed a conceptual framework that characterizes their motivation to own a PCA.

Much research has examined the determinants of pro-environmental behavior. The theory of planned behavior (TPB; Ajzen 1991) and value-belief-norms theory (VBN; Stern et al. 1999), for example, are models that aim to explain the "architecture of cognition" (Bruner 1990) by showing relationships between social-psychological constructs and behavior (Oreg \& Katz-Gerro 2006). These models have been empirically validated and have strong predictive or explanatory value under certain conditions (Kals \& Müller 2012), yet we do not use them here because our question pertains to affect (emotion) and conation (goal-directed action) rather than cognition. That is, we seek to understand the meaning of PCAs to landowners, rather than predict land purchases or model the effect of attitudes, values, or beliefs on behavior.

We find that the desire to be involved directly in a conservation project is an important driver of individual ownership of PCAs. We present a model of PCA engagement illustrating that landowners become invested personally in both the management of the project and in the nature they protect. Fundamental psychological drives for autonomy, efficacy, and social connection facilitate the engagement process, resulting in a sense of purpose and fulfillment. By exploring these motivations, we show how the attributes of PCAs make them particularly life-enriching projects, drawing attention to factors that have been overlooked in research on PLC. Finally, we highlight some implications for practice and suggest ways programs can maximize landowner engagement in PLC.

\section{Methods}

This research utilized a constructivist grounded theory approach (Charmaz 2014) with loosely structured interviews as data. Grounded theory is a structured methodology that begins with inductive analysis and iteratively develops and tests hypotheses within the data (Table 1). The study included interviews with 27 individuals who own a PCA (Table 2). Interviewees were identified through theoretical sampling, which is the process of seeking and collecting pertinent data to clarify and elaborate concepts in the emerging theory (Charmaz 2014). Sampling began from multiple points, with PCA owners identified via internet searches, literature searches, and referral. Recruitment concluded upon reaching theoretical saturation, or the point at which gathering more data about a concept revealed no further properties or theoretical insights (Charmaz 2014). 
Interviewees were selected on the basis of conservation land ownership, which resulted in range of interviewee incomes; interviewees included known high net worth individuals, but many appeared to be of moderate income. The implications of this are considered in the Discussion. All interviewees spoke or wrote in English.

PCAs in this study were heterogeneous. Some but not all properties had formal legal protection. The word "privately" describes ownership and governance rather than use and does not suggest or preclude exclusive access. PCAs included domestic and foreign ownership, residential and nonresidential properties, and variation in size. Many relied on revenue-generating activities, including tourism, breeding, hunting, agriculture, forestry, and easement leases, though only rarely did interviewees imply that earned revenue covered the cost of conservation management.

The lead author conducted all interviews and data analysis. Interviews (average 1hr) were conducted in person or by phone, Skype, or email, as necessary. Interviews began with a request for the landowner to tell the story of how she or he became interested in PLC, with follow-up questions based on responses (see Supporting Information). Interview recordings were transcribed and coded as interviews proceeded, following the comparative analytic process (Charmaz 2006). Coding was initially open and descriptive and gradually became more conceptual. As patterns emerged, they presented new directions for inquiry and clarified the relationships among concepts. Quotes and anecdotes from interviews are included in Table 3 and marked with superscript numbers in the text.

The concepts illustrated by the model were rarely articulated explicitly by landowners. The vocabulary used to explain engagement and all concept definitions presented in Results, whilst derived from interview data, are our own.

Following grounded theory procedures, the study did not begin with an existing theoretical framework. We postponed consultation of the literature until after the core model of engagement was developed, although, per convention, we present the literature here ex ante.

Research ethics were approved by Oxford CUREC, \#SOGE-16-1A-26. An extended description of methods is available online (Supporting Information).

\section{Theoretical Lens: Personal Projects and Well-being}

Following the development of the core model, we discovered that project analytic theory (Little 2014) offered a means of situating our findings (Charmaz 2014). Project analytic theory focuses on individuals' personal strivings in the form of the projects they undertake. Projects in this context are defined endeavors ("from barely noticed routines like 'warm up the car' to overarching life commitments such as 'avenge my father's death,'” Little 1993, p.160). The significance of personal projects as a topic of study derives, in part, from their capacity to represent or reflect aspects of the self. In contrast to tasks done out of necessity, personal projects can be particularly self-expressive, serving as outwardly visible manifestations of an individual's sense of self (Little 1993).

Personal projects analysis, a tool in project analytic theory, has isolated five characteristics that affect well-being (Little et al. 1999):

- Structure: individual initiation of the project and sense of control

- Efficacy: feeling that the project is progressing well and will continue 
- Community: social value and support

- Meaning: subjective worthwhileness

- Stress (inverse): conflict or pressure

The first four factors are positively correlated with well-being, while the final factor, stress, is inversely correlated with well-being. The central notion underlying project analytic theory is that "human happiness and quality of life are intimately related to the context and appraisal of one's ongoing pursuits" (Little et al. 1999, p.514). It follows that, as personal projects, PCAs may impact landowners' quality of life and well-being.

\section{Results}

The experiences and perspectives of PCA owners in this study were diverse, and few categorizations other than conservation interest uniformly characterize the group. However, we found engagement with the conservation property was ubiquitous amongst interviewees. The appeal of owning a PCA is, in large part, about the being personally engaged in meaningful and worthwhile activity.

\section{A Model of PCA Engagement}

Our grounded theory analysis produced a model of engagement with PCAs that includes two potential modes: engagement with the project and engagement with nature (Fig. 1). Engagement with the project is concerned with management, logistics, and decision-making, and its primary concern is how best to implement personal control and responsibility. The result of project engagement is a sense of purpose, which provides a central organizing theme for one's life. Engagement with nature, on the other hand, is about the land, wildlife, trees, and ecosystem, and it is characterized by the experience of being in nature. The result of nature engagement is fulfillment. The two modes of engagement are neither mutually exclusive, nor mutually necessary, but can be mutually reinforcing.

PCAs' affordance of two complementary modes of engagement means that they are a powerful draw for someone looking to make simultaneously a positive impact on the world and enhance their wellbeing. Both engagement with the project and engagement with nature are facilitated by characteristics of PCAs that enable them to meet fundamental - perhaps universal - psychological needs.

In the following sections, we elaborate upon the constituent elements of the model

\section{Engaging with the Project}

Landowners' desire to own a PCA is predicated in part upon their desire to be engaged in a project. Ownership of a PCA differs from a financial donation to a conservation NGO, for example, in that it is "hands-on." Many PCA owners also donate to environmental charities but say doing so does not offer the same depth of personal involvement (Table $3^{1}$ ).

Some landowners live on the PCA premises and are involved in every aspect of management. However, even where nonresident land ownership necessitates professional management, landowners tend to be involved in both big-picture strategy and the particularities of management. One PCA owner reported getting a "real kick" out of building and decorating a lodge, and others featured management dilemmas prominently in their narratives, detailing decisions about reintroductions, stocking rates, culling, and security. 
In some cases, anticipation of the engagement is a true driver of land purchase, with up-front recognition of the potential of the PCA to serve as a project for oneself or to deepen a relationship with family or friends. Others report that they were not looking actively for a PCA, but that it fell into their lives through chance or fate., ${ }^{2,3}$

Project engagement is facilitated by three factors: autonomy, efficacy, and social connection. A desire for autonomy is apparent in many individual PCA owners, and it contributes to the preference for direct ownership over shared governance with NGOs, governments, or collectives. When financially possible, arrangements that allow for independent ownership are preferred because independence means that landowners are able to "call the shots." Usually, desire for autonomy is expressed as a means to an end. For example, landowners report one benefit of private ownership is greater opportunity to experiment (ranging from technical solutions, such as living fenceposts, to integration of cultural and biological conservation). Dealing with other organizations or entities slows experimentation and creates a burden of surplus advice. Similarly, landowners report that working privately is faster and more efficient. Though landowners often seek out partnerships, collaboration in governance entails navigating bureaucracy and is often perceived to reduce the efficiency of operations.

For some, the autonomy of PCA ownership enables exploration of personal values, such as how they believe conservation practices are best implemented. ${ }^{4}$ Wealth increases autonomy; the greater one's resources, the more likely the ability to acquire a conservation property with a high degree of management control. Some people perceived that formal legal protection, such as a conservation easement, decreases autonomy, which is one reason some landowners avoid registering their properties, even when there are tax benefits for doing so.

Second, engagement in a PCA is enhanced to the extent that it offers an opportunity to express efficacy, which in this context is a landowner's ability to observe an effect on the landscape. Many PCA owners note with pride the return of vegetation or wild animals to their properties. Efficacy also includes being able to apply one's skills and talents to the project, including professional skills that are transferrable to conservation. While landowners frequently consult conservation biologists and other scientists, many do not consider specialized knowledge to be a requirement for development or management of a PCA. ${ }^{5}$

PCA owners' views on government's role in conservation vary considerably, though most believe that some government activity (sometimes much) is essential to preserving the world's biodiversity. However, they often contrast these efforts with their own in terms of efficacy. Many perceive conservation by government as slow, inefficient, under-resourced, and unstable. ${ }^{6}$ This view extends to NGOs, particularly large, international conservation organizations. ${ }^{7}$ While some landowners have strong opinions on NGOs, most are more moderate, noting that, because NGOs have more projects in the works, their efforts are spread more thinly; individuals and families are more focused and therefore more efficient.

Lastly, social connection, or the extent to which the conservation project is carried out within a supportive network, contributes to engagement. On most PCAs, at least one other individual is involved in looking after the property, whether family, staff, or contractor. Being "on the same page" 
with the rest of the team contributes to positive feelings about the project. Landowners often collaborate with NGOs and universities for the benefits they bring, not least in terms of social support. When PCAs take the form of a shareblock or conservation development project, there is a sense of collective impact and combined forces. However, collaborations among landowners can be plagued by local politics and power dynamics. Disputes over predators, stocking rates, and permission for access, hunting, or commercial activity lead to increased stress and decreased social connection.

In some parts of the world, formal networks offer an opportunity for conservation landowners to share ideas, best practices, and a sympathetic ear ${ }^{8}$. This seems to be the exception rather than the rule, and it is not unusual for PCA owners to have limited contacts with each other, though connections to NGOs and universities are common. Moreover, in places where PLC is not a familiar concept, landowners occasionally have less-than-harmonious relationships with their neighbors. Local communities may be suspicious about motives, concerned about foreign ownership of land, or disagree about the merits of conservation compared to other land uses. This, too, results in lack of social connection in the context of the project.

\section{Sense of Purpose}

When landowners become highly engaged in the project, the result is a sense of purpose, which provides direction, frames what is important, and organizes the various elements of one's life in relation to a central theme. It is conceptualized in terms of a greater good, with benefits beyond oneself. This sense of purpose is characterized by gratification, personal development, and motivation.

Gratification, in this context, arises when a person feels that the world is a better place because of his or her actions. PCA owners report experiencing a warm, positive feeling from doing the right thing. ${ }^{9,12}$ Some find gratification from sharing the result of their efforts with others, even if visitors are a limited few who can afford it. ${ }^{10}$ A sense of gratification can also influence one's identity. ${ }^{11}$

A sense of purpose also includes personal development, which, here, is a maturing, deepening, or broadening of one's sense of self. The active management, difficult decisions, and coordination of activities and people required by PCA ownership can lead to stress. However, the upside of these challenges is that they result in a feeling of personal growth. Landowners report, for example, that PCA ownership demands new skill development, such as relating to people with different worldviews, finding creative ways to finance operations, or making decisions that involve trade-offs. ${ }^{13}$ Gratification and personal development can propel people to want to do more, creating motivation that drives them to become even more engaged. This feedback loop can make conservation projects a personal mission, even "addictive," according to interviewees. ${ }^{14,15}$

\section{Engaging with Nature}

In a separate but complementary process, PCA owners may also feel engaged with the natural landscape on their property. This engagement creates its own feedback loop, with connection to nature creating the desire for even deeper involvement with the property. Connection to nature is facilitated by familiarity, encounters, solitude, and time.

Familiarity includes knowledge of the landscape. It need not be, and often is not, a scientific understanding, and it encompasses other forms of sense-making, connection, and awareness. 
Landowners describe it as a relationship with the "small things" of the place, the weather, the wildlife, and the landscape. ${ }^{16}$

Engagement with nature is occasionally triggered by encounters with wild animals; though less frequent, it is particularly emotive and transformative. Whether hair-raising encounters with tigers or elephants, or quieter moments when deer allow "the privilege of enjoying them at close quarters," these instances are characterized by a sense of unspoken mutual exchange with wildlife.

The feeling of connection with nature is facilitated by solitude. Many PCA owners use their properties to escape the busyness of everyday life. The desire for quiet is particularly salient, as private reserves allow one to escape the "intrusions, airplanes, and loudmouth campers" encountered in public parks. Artists, especially, describe silence as important to their well-being. ${ }^{17}$

The experience of time in nature differs from time elsewhere. PCA owners relate a slowing of time, enabling familiarity and causing them to feel less hurried. They also allude to cyclical time, which is an awareness of natural cycles: circadian rhythms, such as sequence of animals arriving at a water hole, and seasonal cycles, such as migration. ${ }^{18}$ Being conscious of cyclical time allows landowners to feel in sync with natural rhythms.

\section{Fulfillment}

When individuals are engaged with the PCA's natural environment, they may experience fulfillment, which, in this context, is a situation in which emotional or spiritual needs are satisfied, with a ceasing or lessening of material desires. Unlike sense of purpose, this fulfillment seems to require regular physical presence on the property, which enables a visceral and emotional connection to nature. Fulfillment is characterized by two factors: a sense of connection, and insights or shifts in perspective.

A feeling of connection or oneness can result from spending time reflecting in nature. One landowner speculated that it had to do with ancient human roots as hunter-gathers. ${ }^{19}$ For some, a spiritual connection to nature has always been a part of their lives, but, more typically, spiritual feelings grow with the experience of nature. ${ }^{20}$

Over time, engagement with nature leads to insights and shifts in perspective. Commonly reported shifts are increased ability to think holistically and a heightened sense of personal responsibility. ${ }^{21}$ Many PCA owners also expressed a growing sense of stewardship, feeling that they did not really own the land but were just looking after it for their lifetime. ${ }^{22,23}$

\section{Other Factors}

Project engagement is a ubiquitous, but not sole, explanation for PCA owners' actions. In interviews, landowners described other factors that motivated them, including:

- Instrumental use: making an investment, using a property for recreation or residence

- Contribution: leaving a legacy, creating a movement

- Knowledge and emotions: responding to ecological knowledge, falling in love with an area, feeling love for and protecting animals 
These factors were compelling for some individuals but did not broadly characterize PCA ownership or explain why landowners expressed their desires and values specifically through land purchase; this was only found in the concept of engagement.

\section{Discussion}

We began by querying individual landowners' motives to own a PCA. We found that PCA ownership is neither purely philanthropic nor purely self-interested; it also provides an opportunity to engage in functional leisure activity that is both enjoyable and productive (Farmer et al. 2016). For landowners, a PCA is a constitutive element of a happy and virtuous life: a project that achieves well-being through "well-doing" (Little 2014). Our analysis extends others' findings (van den Born et al. 2017; Chan et al. 2016), showing that well-being motives constitute a "third pillar" in the justification of PLC.

In our ex post consultation of the literature, we found the psychological factors that facilitate PLC project engagement - autonomy, efficacy, and social connection - closely mirror the key characteristics identified through project analytic theory, which explores the relationship between personal projects and well-being (Little 1999). ${ }^{i}$ This implies that drivers of PCA ownership have much in common with drivers of other personal endeavors.

However, project analytic theory recognizes two additional factors: meaning and stress (Little 1999). Meaning is not a facilitator in our PCA engagement model, but rather serves as the context - a global biodiversity crisis - in which engagement takes place. Project analytic theory also suggests stress is an inverse predictor of well-being. Interviewees in the present study commonly describe PCA ownership as a source of stress, yet they also report their projects to be among the most gratifying aspects of their lives. One explanation of this contradiction lies in the dual components of the PCA engagement model: engagement with both the project and nature. Separately, each is applicable to other domains, such as a conservation research project or walking in the woods. PCA ownership includes both. This combination may draw its emotional power from the fact that spending time in nature provides resilience against the stress that accompanies such a project (Clayton \& Myers 2015) and serves as a restorative resource (Little 2014). This seems to be a winning combination for an engaging and lifeenriching project.

In research on motives, the locus of motivation - intrinsic or extrinsic - is a central concern. Intrinsic motivation, or the drive to do something because it is inherently interesting or enjoyable, contrasts with extrinsic motivation, or the drive toward something because it leads to a separable outcome, such as a reward (Ryan \& Deci 2000). The distinction between intrinsically and extrinsically motivated behavior is consequential in conservation policy, where the merits of providing financial incentives in exchange for pro-environmental behavior are debated (Stern 2006). Apprehension arises from the finding that external incentives can "erode" or "crowd out" pre-existing intrinsic motivation, leading to a situation in which the desired behavior is dependent upon continued incentivization (Rode et al. 2015).

\footnotetext{
'Note, too, the parallels with self-determination theory (Ryan \& Deci 2000).
} 
In our study, motives associated with living a meaningful life would be considered intrinsic (Ryan \& Deci 2000), yet we believe our findings are also relevant to extrinsic motivation. Most policy instruments are considered extrinsic, and therefore risk crowding out intrinsic motivation (Rode et al. 2015). However, extrinsic motivation varies along a continuum, from external regulation to integration (Figure 2), based on the degree to which actors perceive autonomy in the promoted action - and, consequently, the degree to which they internalize extrinsic motivation (Ryan \& Deci 2000). For example, a financial payment may prompt conservation behavior purely for the reward (less autonomous) or because the payment increases the benefits of action consistent with the landowner's values (more autonomous). Perception of autonomy depends not on the type of policy, but on whether the policy is implemented in a way that supports autonomy and self-determination (Cetas \& Yasué 2016). This suggests policy instruments that support autonomy, efficacy, and social connection are more likely to foster internalization of extrinsic motivation. Moreover, these policies are also more likely to lead to positive conservation outcomes in a variety of contexts, including populations not characterized by personal wealth, such as in community-based conservation areas (Cetas \& Yasué 2016).

Interviewees in this study constitute a specific sub-population in PLC: those who have both the motivation and resources to own land for conservation purposes. This sub-population is important to conservation because of their potential to make contributions to global land protection. Because our study focused on individuals with financial resources, we are cautious about applying our findings too broadly. However, we are also heartened by the consistency of our findings with research featuring people of diverse backgrounds (Cetas \& Yasué 2016), which suggests similar factors may motivate people more broadly.

Ultimately, we have found that the facilitators of project engagement in people who own PCAs are the very factors that facilitate a broader range of landowners to internalize extrinsic motivators, such as incentives (Ryan \& Deci 2000). This is significant because it implies that policymakers need not know a particular individual's locus of motivation; whether the motivation is intrinsic or extrinsic, whether people are self-motivated or incentivized, policy that enables autonomy, efficacy, and social connection is more likely to benefit both the natural environment and human well-being.

\section{Facilitating Autonomy, Efficacy, and Social Connection}

Despite the exploratory and qualitative nature of this study, the results signal potential implications for conservation policy, particularly when viewed in the context of research on intrinsic and extrinsic motivation in other groups (Cetas \& Yasué 2016). One direct implication of our findings is that PLC programs may be more appealing to landowners to the extent that they permit landowner autonomy (Morrisette 2001). Of course, simultaneously maximizing both landowner autonomy and program effectiveness is difficult, as NGOs and governments that aim to encourage conservation on land owned by individuals must encourage the use of best practices and measure program outcomes. The present study reveals a desire for autonomy even among the most conservation-minded of landowners, suggesting that lack of autonomy may dissuade some landowners from participating in prescriptive programs. For this reason, implementing policy instruments in a way that supports landowner autonomy is likely to increase its appeal (Cetas \& Yasué 2016). The desire for autonomy we find here echoes not only the psychology literature, but also research on land ownership in 
general, particularly where strong property rights are valued (Raymond \& Olive 2008).

Counterintuitively, the attractiveness of restrictive easements (Cooke \& Corbo-Perkins 2018, Ernst \& Wallace 2008) may in fact lie in their ability to perpetuate a landowner's self-determination; this "codified autonomy" provides assurance that a landowner's work will not be undone by successors, or an uncertain future.

Second, PCA owners use their projects as a means of expressing positive efficacy, e.g., as an opportunity to apply prior knowledge (Welsh et al. 2018) or develop new skills. In this study, many PCA owners determined their effectiveness by intuition and observation, noting the restoration of vegetation and return of wildlife in response to conservation action. Even where formal monitoring programs are in place, we note that most guidance arises from the biological and ecological sciences, with little available to landowners concerning governance, social context, or sustainable finance. Resources such as the Land Trust Standards and Practices (www.landtrustalliance.org) and the forthcoming IUCN Best Practice Guidelines for Privately Protected Areas (www.privateconservation.net) help codify best practices, creating models against which PCA owners can judge their efficacy.

Lastly, the importance of social support for one's endeavors is apparent here and well-documented elsewhere (e.g., Baumeister \& Leary 1995). Networks are a powerful tool for facilitating engagement (Bodin \& Crona 2009). Presently, outside a few clusters, PCA owners have little opportunity to exchange information, ideas, and support with each other, but networks could serve this purpose and act as a delivery mechanism for the aforementioned best practice guidelines. Organizations such as the International Land Conservation Network and others worldwide may be well-placed to serve this role. While peer-to-peer landowner networks will be most feasible at a regional scale (e.g., Así Conserva Chile), research is also needed to assess the utility of developing a network for owners of large-scale PCAs, who face unique challenges ecologically, organizationally, and financially.

Grounded theory is intended to generate models: in line with this, we have introduced a model of PCA engagement, based on a close analysis of empirical data, upon which future research can build. Working across a variety of cultural and policy contexts has enabled us to identify the common thread of engagement woven throughout individual PCA owners' accounts of their involvement in PLC. The next step is to validate this framework in other contexts of PCA decision-making and action. Yet, given the consistency of these findings with psychological literature, we believe this research has already yielded insights that are applicable and useful to both theory and practice. Because project engagement is a strong motivator for landowners, policy that fosters engagement through landowner autonomy, efficacy, and social connection has strong potential to deliver benefits to both conservation and well-being.

\section{Supporting Information}

Online supporting information includes an extended methods section and an interview guide. 


\section{References}

Ajzen I. 1991. The theory of planned behavior. Organizational Behavior and Human Decision Processes 50(2): 179-211

Baumeister RF, Leary MR. 1995. The need to belong: Desire for interpersonal attachments as a fundamental human motivation. Psychological Bulletin 117(3):497-529.

Bodin B, Crona C. 2009. The role of social networks in natural resource governance: What relational patterns make a difference? Global Environmental Change 19(3):366-74.

Bruner J. 1990. Acts of Meaning. Cambridge, MA: Harvard University Press.

Cetas ER, Yasué M. 2016. A systematic review of motivational values and conservation success in and around protected areas. Conservation Biology 31(1):203-212.

Chan K, Balvanera P, Benessaiah K, Chapman M, Díaz S, Gómez-Baggethun E, Gould R, et al. 2016. Why protect nature? Rethinking values and the environment. Proceedings of the National Academy of Sciences of the United States of America 113(6): 1462-1465.

Charmaz K. 2006. Constructing Grounded Theory. Sage Publications, London.

Ciuzio E, Hohman WL, Martin B, Smith MD, Stephens S, Strong AM, Vercauteren T. 2013. Opportunities and challenges to implementing bird conservation on private lands. Wildlife Society Bulletin 37(2): 267-277.

Clayton S, Myers G. 2015. Conservation Psychology: Understanding and Promoting Human Care for Nature. $2^{\text {nd }}$ ed. Wiley-Blackwell, Chichester, UK.

Cooke, Benjamin and Gabriella Corbo-Perkins. 2018. Co-opting and resisting market based instruments for private land conservation. Land Use Policy 70:172-181.

Drescher M. 2014. What is it like to take care of the land? Toward an understanding of private land conservation. Rural Society 23(2):117-32.

Drescher M, Brenner J. 2018. The practice and promise of private land conservation. Ecology and Society $\mathbf{2 3}(2)$.

Emmons RA, King LA. 1988. Conflict among personal strivings: Immediate and long-term implications for psychological and physical well-being. Journal of Personality and Social Psychology 54(6):1040-1048.

Ernst T, Wallace GN. 2008. Characteristics, motivations, and management actions of landowners engaged in private land conservation in Larimer County, Colorado. Natural Areas Journal 28(2):109120.

Fairfax SK, Gwin L, King MA, Raymond L, Watt LA. 2005. Buying Nature: The Limits of Land Acquisition as a Conservation Strategy, 1780-2004. MIT Press, Cambridge.

Farmer J, Brenner J, Drescher M, Dickinson S, and Knackmuhs E. 2016. Perpetual private land conservation: The case for outdoor recreation and functional leisure. Ecology and Society 21(2): 46. 
Farmer JR, Knapp D, Meretsky VJ, Chancellor C, Fischer BC. 2011. Motivations influencing the adoption of conservation easements. Conservation Biology 25(4):827-34.

Fischer R, Schwartz S. 2010. Whence differences in value priorities? Journal of Cross-Cultural Psychology 42(7):1127-44.

Kabii T, Horowitz P. 2006. A review of landholder motivations and determinants for participation in conservation covenanting programmes. Environmental Conservation 33(1):11.

Kals E, Müller M. 2012. Emotions and the Environment. In Clayton S, editor. The Oxford Handbook of Environmental and Conservation Psychology. OUP, Oxford.

Kamal, S, Grodzińska-Jurczak, M, and Brown, G. 2015. Conservation on private land: A review of global strategies with a proposed classification system. Journal of Environmental Planning and Management Journal of Environmental Planning and Management 58(4): 576-597.

Little BR. 1999. Personality and motivation: Personal action and the conative evolution. In Pervin LA, John OP, editors. Handbook of Personality: Theory and Research. 2nd ed. Guilford Press, New York.

Little BR. 1993. Personal projects and the distributed self: Aspects of a conative psychology. In Suls J, editor. Psychological Perspectives on the Self: The Self in Social Perspective. Psychology Press, New York.

Little BR. 2014. Well-doing: Personal projects and the quality of lives. Theory and Research in Education Theory and Research in Education 12(3): 329-346.

Lokhorst AM, Staats H, van Dijk J, van Dijk E, and de Snoo G. 2011. What's in it for me? Motivational differences between farmers' subsidised and non-subsidised conservation practices. Applied Psychology 60(3): 337-353

Morrisette P. 2001. Conservation easements and the public good: Preserving the environment on private lands. Natural Resources Journal 41(2): 373-426.

Oreg S, Katz-Gerro T. 2006. Predicting proenvironmental behavior cross-nationally: Values, the theory of planned behavior, and value-belief-norm theory. Environment and Behavior 38(4): 462-483. Pagès M, Fischer A, van der Wal R. 2017. The dynamics of volunteer motivations for engaging in the management of invasive plants: Insights from a mixed-methods study on Scottish seabird islands. Journal of Environmental Planning and Management 21:1-20.

Raymond L, Olive A. 2008. Landowner beliefs regarding biodiversity protection on private property: An Indiana case study. Society and Natural Resources 21(6):483-497.

Rode J, Gómez-Baggethun E, Krause T. 2015. Motivation crowding by economic incentives in conservation policy: A review of the empirical evidence. Ecological Economics 109:80.

Rogers EM. 1995. Diffusion of Innovations. Free Press, New York.

Ryan RM. 2010. Pursuing pleasure or virtue: The differential and overlapping well-being benefits of hedonic and eudaimonic motives. Journal of Happiness Studies 11(6): 735-762. 
Ryan RM, Deci EL. 2000. Intrinsic and extrinsic motivations: Classic definitions and new directions. Contemporary Educational Psychology 25(1):54-67.

Selinske MJ, Coetzee J, Purnell K, Knight AT. 2015. Understanding the motivations, satisfaction, and retention of landowners in private land conservation programs. Conservation Letters 8(4):282-289.

Stern, P C, T Dietz, T Abel, G A Guagnano, and L Kalof. 1999. A value-belief-norm theory of support for social movements: The case of environmentalism. Human Ecology Review 6(2):81-98.

Stern S. 2006. Encouraging conservation on private lands: A behavioral analysis of financial incentives. Arizona Law Review 48:541-83.

Stolton S, Redford KH, Dudley N. 2014. The Futures of Privately Protected Areas: Developing Capacity for a Protected Planet. IUCN, Gland, Switzerland.

van den Born RJ, Arts B, Admiraal J, Beringer A, Knights P, Molinario E, et al. 2017. The missing pillar: Eudemonic values in the justification of nature conservation. Journal of Environmental Planning and Management 11:1-16.

Welsh R, Webb M, Langen T. 2018. Factors affecting landowner enrollment in wetland restoration in northeastern New York state. Land Use Policy 76:679-685. 


\section{Figures}

Figure 1

\section{Model of Engagement}

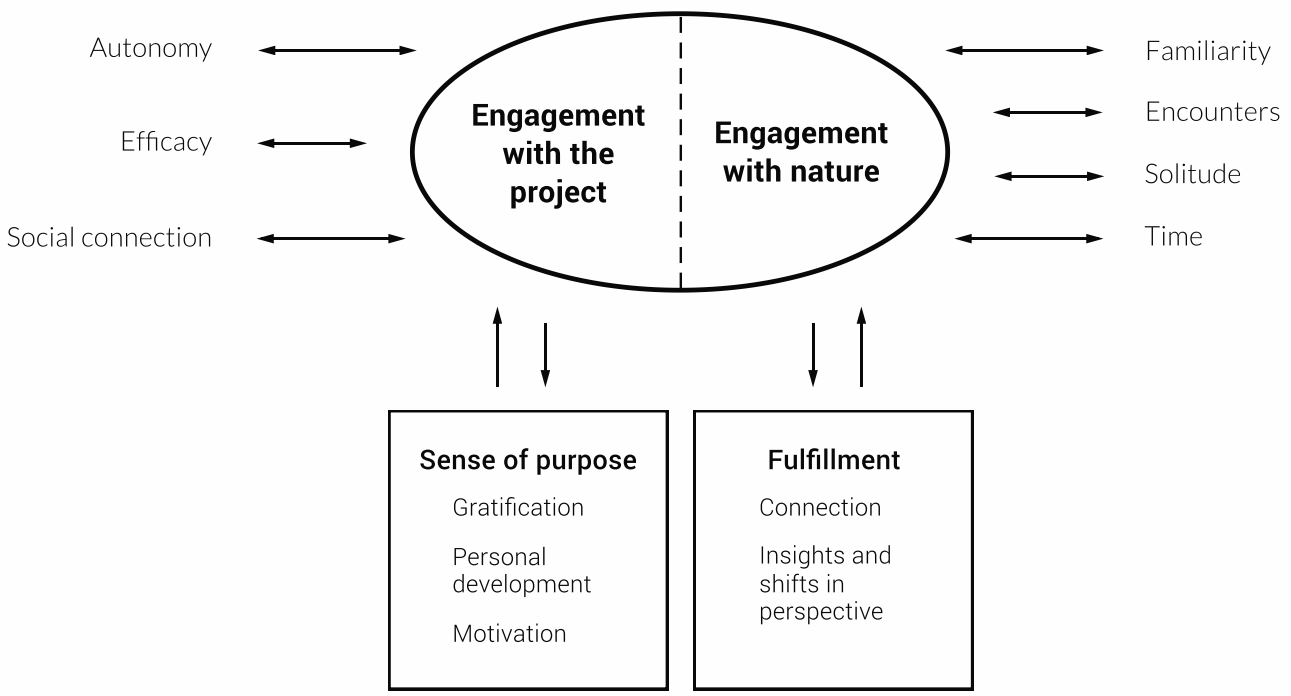

Figure 1. This model of PCA engagement shows that private land conservation includes both engagement with the project and engagement with nature; engagement is facilitated by multiple factors and associated with well-being.

Figure 2

\section{Extrinsic and Intrinsic Motivation}

Extrinsic Motivation

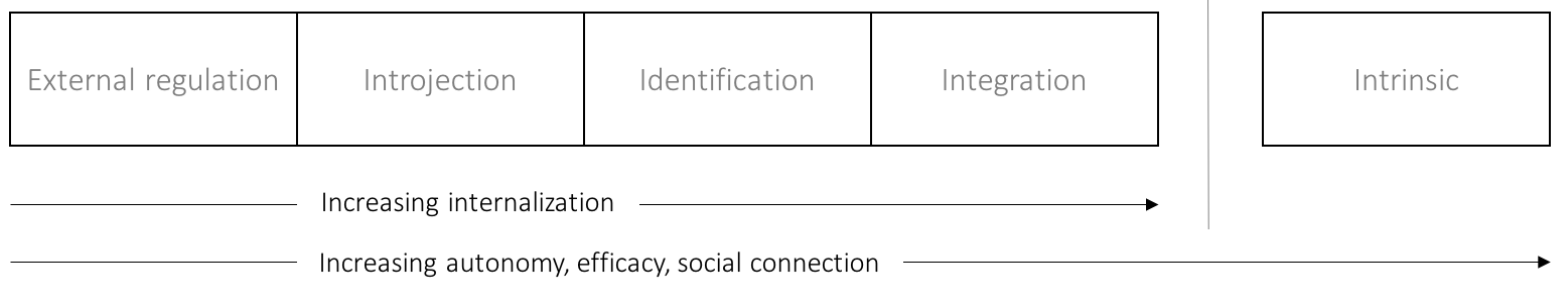

Adapted from Ryan \& Deci (2000)

Figure. 2. Extrinsic and intrinsic motivation are categorically distinct, but extrinsic motivation varies along a continuum affected by degree of autonomy, efficacy, and social connection; the greater the presence of these factors, the more internalized and extrinsic motivator will be. External regulation, introjection, identification, and integration are categories of extrinsic motivation that represent increasing degree of internalization. 


\section{Tables}

Table 1

\begin{tabular}{|c|c|}
\hline \multicolumn{2}{|l|}{ Methods at a glance } \\
\hline Methodology & Grounded theory \\
\hline Purpose & $\begin{array}{l}\text { To generate new theory; theory defined as a statement of the relationship } \\
\text { between abstract concepts that aims for either explanation or understanding } \\
\text { (Charmaz 2014); as aim, theory generation is contrasted with theory } \\
\text { verification }\end{array}$ \\
\hline Data source & $\begin{array}{l}\text { Loosely-structured interviews; avg. duration 1h; conducted by lead author in } \\
\text { person or by phone, Skype, or email, as necessary }\end{array}$ \\
\hline Target population & $\begin{array}{l}27 \text { individuals who owned a PCA; PCA is defined as privately-owned land } \\
\text { for which conservation was a main (not necessarily sole) objective, as } \\
\text { expressed by landowner; } 2 \text { interviewees were descendants of the original } \\
\text { landowners who provided secondhand accounts of their parents' experiences }\end{array}$ \\
\hline \multirow[t]{4}{*}{ Analysis } & Grounded theory methodology; conducted by lead author; core tools included: \\
\hline & $\begin{array}{l}\text { - Coding: Coded following each interview; coding was not completed in } \\
\text { rounds but continued throughout study as comparisons were made within the } \\
\text { data set }\end{array}$ \\
\hline & $\begin{array}{l}\text { - Comparative analysis: Transcript text was compared within and across } \\
\text { interviews for similarities and differences, informing codes and memos; a.k.a. } \\
\text { "constant comparison" }\end{array}$ \\
\hline & $\begin{array}{l}\text { - Memos: } 374 \text { analytical, process, source, and other memos were written in } \\
\text { the analysis. }\end{array}$ \\
\hline Sampling & $\begin{array}{l}\text { Theoretical sampling: Began with internet search, literature search, and } \\
\text { referral; sought to maximize diverse viewpoints and geographical } \\
\text { representation within target population; sampling targets evolved as analysis } \\
\text { unfolded }\end{array}$ \\
\hline Saturation & $\begin{array}{l}\text { The study concluded upon reaching theoretical saturation, when coding of } \\
\text { additional transcripts revealed no new concepts (i.e., codes or variables) or } \\
\text { properties (characteristics) of concepts; for the model presented here, this } \\
\text { occurred after approximately } 21 \text { interviews }\end{array}$ \\
\hline
\end{tabular}

Table 1. Details of the application of grounded theory; an extended methods description and interview guide are available in online Supporting Information.

$\underline{\text { Table } 2}$

Interviewee characteristics 


\begin{tabular}{|l|l|l|l|l|}
\hline Region & Countries & Male & Female & $\begin{array}{l}\text { Avg. property size } \\
\text { (ha) }\end{array}$ \\
\hline Africa & South Africa, Zimbabwe & 4 & 0 & 47,720 \\
\hline Asia & India & 1 & 1 & 80 \\
\hline Europe & Scotland, Spain & 1 & 2 & 2,780 \\
\hline Oceania & Australia, New Zealand & 0 & 2 & 3,860 \\
\hline North America & Canada, Mexico, United States & 5 & 2 & 20,080 \\
\hline South America & Chile, Colombia, Argentina & 5 & 4 & 7,580 \\
\hline $\begin{array}{l}\text { Professional backgrounds included business, industry, retail, tourism, consulting, economics, real } \\
\text { estate, science, art, music, ranching, and farming. }\end{array}$
\end{tabular}

Table 2. Interviewees included 27 individuals with conservation properties of varying size in 13 countries on 6 continents.

Table 3

\begin{tabular}{|c|c|c|}
\hline \multicolumn{3}{|c|}{ Results: A Model of PCA Engagement } \\
\hline $\begin{array}{l}\text { Quote } \\
\text { number }\end{array}$ & $\begin{array}{l}\text { Interviewee } \\
\text { ID }\end{array}$ & Quotation \\
\hline \multicolumn{3}{|c|}{ Engaging with the Project } \\
\hline 1 & F455 & $\begin{array}{l}\text { One landowner explained, "If you give money to a charitable } \\
\text { organization, you don't have the intimate relationship with the land, the } \\
\text { science, the opportunity to show students, to teach, to share. It's the } \\
\text { difference between putting a toe in the water versus being immersed." }\end{array}$ \\
\hline 2 & F455 & $\begin{array}{l}\text { One landowner submitted a low bid on a property, for fun, while on } \\
\text { holiday. When the higher bidder's deal fell through, she ended up with a } \\
\text { large, degraded cattle farm, the restoration of which became her life's } \\
\text { vocation. }\end{array}$ \\
\hline 3 & M127 & $\begin{array}{l}\text { One landowner, unbeknownst to him, was left an option to purchase a } \\
\text { PCA in the will of a man he barely knew; when the prior owner died and } \\
\text { the will was made known, he felt fate had intervened and purchased the } \\
\text { property. }\end{array}$ \\
\hline 4 & M342 & $\begin{array}{l}\text { One reported, "I wanted autonomy to decide how to manage the place } \\
\text { and decide on my own vision of what conservation is and what it } \\
\text { means." In this case, the PCA functioned as a space for testing abstract } \\
\text { conservation values in the real world, with the response of the landscape } \\
\text { as feedback. }\end{array}$ \\
\hline
\end{tabular}




\begin{tabular}{|c|c|c|}
\hline 5 & M122 & $\begin{array}{l}\text { Explaining the advantage of his background in real estate, one landowner } \\
\text { noted, "Most [NGOs] are run by scientists and attorneys anyway - if you } \\
\text { know what I mean," implying that skills beyond science and law are, in } \\
\text { fact, required for effectiveness. }\end{array}$ \\
\hline 6 & F426 & $\begin{array}{l}\text { "There should be government protection. But...we may have a good } \\
\text { government that understands today, or we may have the opposite } \\
\text { thinking, or none at all.... This made us realize that the best way to } \\
\text { protect nature was on our own or with friends." }\end{array}$ \\
\hline 7 & M342 & $\begin{array}{l}\text { "I can tell you right now, a few of them are doing some good, but a lot of } \\
\text { them are wasting a lot of money. I'm just not overly impressed with the } \\
\text { majority of the big conservation NGOs. I think they blow a lot of hot air. } \\
\text { I think they waste a lot of money." }\end{array}$ \\
\hline 8 & $\begin{array}{l}\text { F252 } \\
\end{array}$ & $\begin{array}{l}\text { When asked about her membership in a landowner network, one replied, } \\
\text { "We go together to promote [private land conservation] and to talk to the } \\
\text { authorities. Our aim is to have legislation that respects private reserves... } \\
\text { We do some lobbying together and we exchange information. It's like a } \\
\text { club... Yes, you feel better to be together." }\end{array}$ \\
\hline \multicolumn{3}{|c|}{ Sense of Purpose } \\
\hline 9 & F233 & $\begin{array}{l}\text { One landowner wrote, "To think that I've protected habitat even just for } \\
\text { one creature makes me feel very fulfilled. I feel like I'm making a } \\
\text { positive difference in my little pocket of the world." }\end{array}$ \\
\hline 10 & M127 & $\begin{array}{l}\text { "I hope that the people who go there stick their feet in the sand and get a } \\
\text { bit of that feeling because then it would all be worthwhile." }\end{array}$ \\
\hline 11 & M336 & $\begin{array}{l}\text { Those who purchase land with a conservation objective feel "like they're } \\
\text { actually doing something. It's not just, 'Here's my bush home.' The bush } \\
\text { home is a bonus," adding, "Actually, it is more. It's: 'I'm a } \\
\text { conservationist now.'” Here, moving beyond a purchase that is self- } \\
\text { serving to one that the landowner sees as a positive contribution provides } \\
\text { the substance for a landowner to self-identify as a conservationist. }\end{array}$ \\
\hline 12 & M101 & $\begin{array}{l}\text { Summing up his experience, one PCA owner commented, "It's a hobby, a } \\
\text { very expensive hobby. I have other hobbies...hunting and sailing, and I } \\
\text { do just about every sport that there is. But the thing is, I don't think I've } \\
\text { ever done anything that has felt so good." }\end{array}$ \\
\hline
\end{tabular}




\begin{tabular}{|c|c|c|}
\hline 13 & F332 & $\begin{array}{l}\text { One landowner explained, "You need to be able to talk to people with a } \\
\text { lot of feeling, understanding their point of view - not just talking at } \\
\text { them, but talking with them... I think, from the point of view of a } \\
\text { learning process, there is nothing better than being a steward of land } \\
\text { because you have to see things from different angles." }\end{array}$ \\
\hline 14 & F266 & $\begin{array}{l}\text { "The possibility of preserving an ecosystem as fragile as the one that one } \\
\text { finds in [this area] makes us feel that we have a mission and an } \\
\text { obligation to fulfill." }\end{array}$ \\
\hline 15 & F426 & $\begin{array}{l}\text { Another described: "It was a lot of sacrifice. In [the mountains] we had } \\
\text { no cell, radio, or TV, and we were cut off for months in the monsoon } \\
\text { season. But peace and fulfillment come from within. You can't get it any } \\
\text { other way than the heart of nature. When you have that experience, it } \\
\text { propels you to do more. You have to do more." }\end{array}$ \\
\hline \multicolumn{3}{|c|}{ Engaging with Nature } \\
\hline 16 & F332 & $\begin{array}{l}\text { One landowner noted, "I've been taught to see and to value and to want } \\
\text { to learn more. Every time I see a toad, for example, one of the basest of } \\
\text { animals, I wonder if it's a female or male or what's it doing. Why has it } \\
\text { come out? How long is it going to stay here? It just adds so much more } \\
\text { interest to your life." }\end{array}$ \\
\hline 17 & M232 & $\begin{array}{l}\text { "As a musician I like silences, and I wanted a refuge. Most of my best } \\
\text { melodies are composed when I go there. So that sheer silence and } \\
\text { loneliness of the place also attracted me." }\end{array}$ \\
\hline 18 & F332 & $\begin{array}{l}\text { One landowner observed, "You see that the birds have arrived back from } \\
\text { Africa, and you feel very, very proud, in a good sense, of the things that } \\
\text { are changing. You feel proud that this land can be appreciated, not only } \\
\text { by people but by animals themselves." }\end{array}$ \\
\hline \multicolumn{3}{|c|}{ Fulfillment } \\
\hline 19 & M342 & $\begin{array}{l}\text { "I think there's a spiritual something that one gets, some ancient } \\
\text { connection to our hunter-gatherer roots that one feels and that one wants } \\
\text { to somehow recreate and relive." }\end{array}$ \\
\hline 20 & M232 & $\begin{array}{l}\text { "I think I've become far more spiritually inclined... I can now visualize } \\
\text { myself dying and then my life energy absorbed by a tree, or by a creature } \\
\text { which feeds on me. It gets passed on, and I get to live in another form, in } \\
\text { another creature or in another tree... It's that flow of life energy that I } \\
\text { now feel completely synergized with. Before I didn't understand it." }\end{array}$ \\
\hline
\end{tabular}




\begin{tabular}{|r|l|l|}
\hline 21 & M427 & $\begin{array}{l}\text { A rancher said that, before beginning restoration activities on the land, } \\
\text { when there were problems, he would visit the vet or the pharmacy for the } \\
\text { solution. "Now it's very, very different. When something happens to the } \\
\text { ranch, then I go to the mirror and say, 'What am I doing? What am I } \\
\text { doing wrong?'...That's how it changes your mindset." }\end{array}$ \\
\hline 22 & F332 & $\begin{array}{l}\text { "That's my feeling, that you don't really own it. You really are just } \\
\text { guarding it during your lifetime. Although it sounds a bit airy-fairy for } \\
\text { people who don't understand that kind of ownership, I think you have to } \\
\text { keep that in the back of your mind all the time." }\end{array}$ \\
\hline 23 & M127 & $\begin{array}{l}\text { One landowner felt that owning a vast property shifted his perspective of } \\
\text { space and time: "A project like this, the size it is, you can't believe it's } \\
\text { yours. The world continues for millennia and you're a temporary blip on } \\
\text { the thing, and you have to do what you can in that time." }\end{array}$ \\
\hline
\end{tabular}

Table 3. Quotes and anecdotes from interviews, which are referenced with superscript numbers in Results. Interview ID: $\mathrm{F}=$ female, $\mathrm{M}=$ male. 